\title{
SUMMARY ANNUAL REPORT
}

MAY 1998 - APRIL 1999

\section{NYE COUNTY NUCLEAR WASTE REPOSITORY PROJECT OFFICE INDEPENDENT SCIENTIFIC INVESTIGATIONS PROGRAM}

GRANT DE-FG08-96NV12027

HYDROLOGIC INVESTIGATIONS CONDUCTED BY:

Multimedia Environmental Technology, Inc.

JULY 1999 


\section{DISCLAIMER}

This report was prepared as an account of work sponsored by an agency of the United States Government. Neither the United States Government nor any agency thereof, nor any of their employees, make any warranty, express or implied, or assumes any legal liability or responsibility for the accuracy, completeness, or usefulness of any information, apparatus, product, or process disciosed, or represents that its use would not infringe privately owned rights. Reference herein to any specific commercial product, process, or service by trade name, trademark, manufacturer, or otherwise does not necessarily constitute or imply its endorsement, recommendation, or favoring by the United States Government or any agency thereof. The views and opinions of authors expressed herein do not necessarily state or reflect those of the United States Government or any agency thereof. 


\section{DISCLAIMER}

Portions of this document may be illegible in electronic image products. Images are produced from the best available original document. 


\section{TABLE OF CONTENTS}

SUMMARY ANNUAL REPORT .......................................................... 1

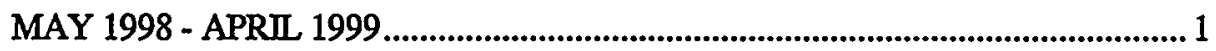

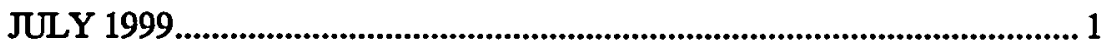

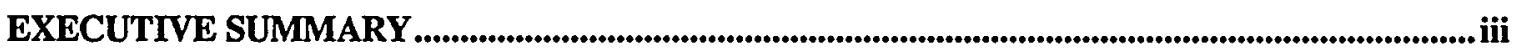

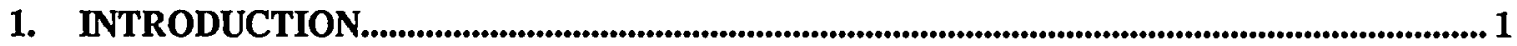

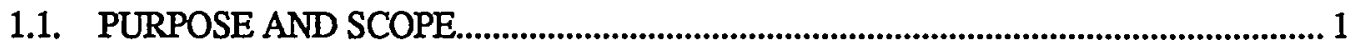

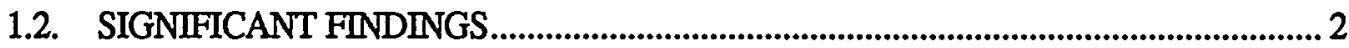

2. MONITORING ONC\#1, NRG-4, ESF TUNNEL, AND ECRB DRIFT ........................................... 4

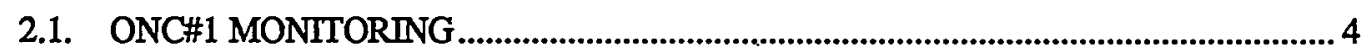

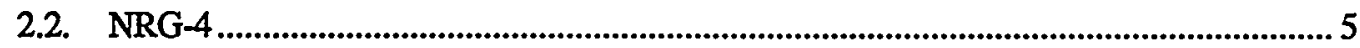

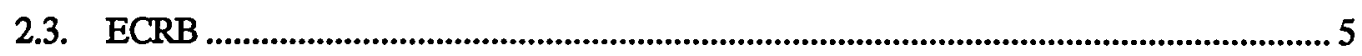

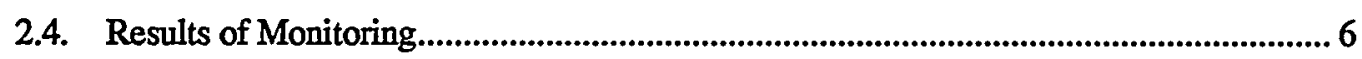

3. GAS SAMPLING FROM ONC\#1

4. EVALUATION OF SATURATED ZONES HYDROLOGY

4.1. REGIONAL HYDROGEOLOGICAL MODELING .................................................

4.1.1. PROCEDURES FOR SATURATED-ZONE MODEL SETUP.............................. 10

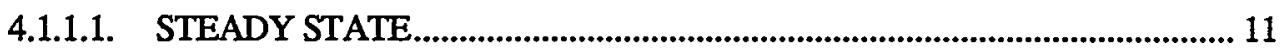

Verification simulation with USGS model:................................................................11

Simulations of AVYM model using constant head boundaries: ................................. 11

Converting all boundary nodes of the AVYM to general head boundaries:................... 11

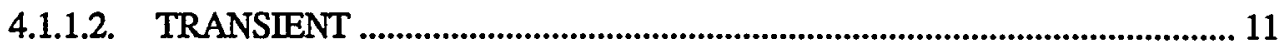

4.1.2. AMARGOSA VALLEY FLOW SYSTEM BOUNDARIES................................ 12 


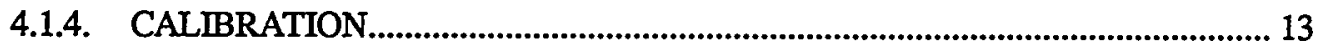

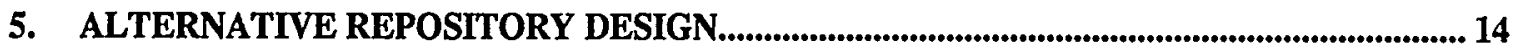

5.1. TUNNEL INSTRUMENTATION AND DATA ....................................................... 14

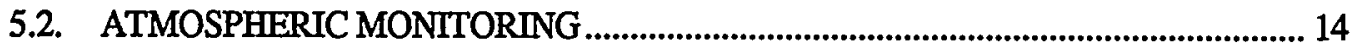

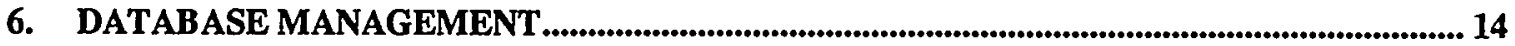

7. SUMMARY REPORT OF PROCEEDINGS of the WORKSHOP ON VENTILATED REPOSITORY DESIGN.......................................................................................................................... 15

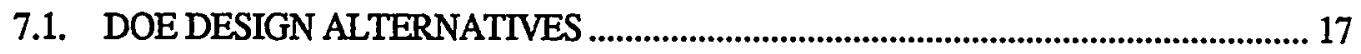

7.2. HYDROLOGIC IMPACTS OF A NATURALLY VENTILATED REPOSITORY ...... 18

8. REFERENCES .................................................................................................................................................. 20

\section{LIST OF FIGURES}

Figure 1-1 Topography, location of selected boreholes, ESF centerline, and ECRB at Yucca Mountain Site.

Figure 4.1 - Location map of the Amargosa Vallev/Yucca Mountain model in relation to the USGS model (D'Agnese et. a.. 1996)

Figure 4.2 - Contour map of average water levels measured in wells from 1947 to 1997.

Figure 2-1 Schematic profile of instrumentation setup in UE-25 ONC\# 1 and USW NRG-4.

Figure 4.3 - AVYM transient simulation results. $K$ in layer 1 is limited to a maximum of $0.01 \mathrm{~m} / \mathrm{d}$ except in alluvial fill which is $30000 \mathrm{~m}$ wide (10 cells), $500 \mathrm{~m}$ thick, and has a $\mathrm{K}$ of $1 \mathrm{~m} / \mathrm{d}$.

Figure 4.4 - Grid and boundary of the Amargosa valley/Yucca mountain model

Figure 5-1 Oblique view of the modified unsaturated zone mesh. 


\section{EXECUTIVE SUMMARY}

This annual summary report, prepared by the Nye County Nuclear Waste Repository Project Office (NWRPO), summarizes the activities that were performed during the period from May 1, 1998 to April 30, 1999. These activities were conducted in support of the Independent Scientific Investigation Program (ISIP) of Nye County at the Yucca Mountain Site (YMS).

The Nye County NWRPO is responsible for protecting the health and safety of the Nye County residents. NWRPO's on-site representative is responsible for designing and implementing the ISIP. Major objectives of the ISIP include:

$>$ Investigating key issues related to conceptual design and performance of the repository that can have major impact on human health, safety, and the environment.

$>$ Identifying areas not being addressed adequately by DOE.

Nye County has identified several key scientific issues of concern that may affect repository design and performance which were not being adequately addressed by DOE. Nye County has been conducting its own independent studies to evaluate the significance of these issues.

The reader is referred to previous reports (NWRPO, 1995; MET, 1995; MET, 1996; MET, 1997, and NWRPO, 1998) for detailed explanation of these specific concerns.

This report summarizes the results of monitoring from two boreholes and the Exploratory Study Facility (ESF) tunnel that have been instrumented by Nye County since March and April 1995. The preliminary data and interpretations presented in this report do not constitute and should not be considered as the official position of Nye County. Also included in this summary report is the use of the data obtained from the Early Warning Drilling Program (EWDP) of Nye County in development of the Saturated Zone modeling of the area of concern. A comprehensive groundwater database has been developed and is updated regularly as part of the saturated zone modeling effort.

The ISIP presently includes borehole and tunnel instrumentation, monitoring, data analysis, and numerical modeling activities to address the concerns of Nye County.

Several important issues were identified and studied during this period of the investigations:

$>$ The need for investigating alternative repository design was discussed and evaluated during the workshop held by Nye County in December 1998. It was realized that the elevated temperature of the canisters and its effect on the repository are extremely complicated to 
analyze. The consensus was that an alternative low temperature repository design should be carefully studied.

$>$ Data from the Exploratory Studies Facility (ESF) and Enhanced Characterization of the Repository Block (ECRB) showed that tunnel instrumentation for environmental and ventilation parameter characterization should be done at various cross-sections. Ventilation experiments need to be designed to obtain data at conditions predicted for the repository.

$>$ Modeling of natural ventilation indicated that modification of the A-TOUGH code is necessary to provide capability for the coupled effect of the heat and moisture transfer between the rock and the tunnel air.

$>$ Modeling of the saturated zone and incorporation of the preliminary data from the EWDP indicated that the current DOD conceptual model of the valley fill deposits needs to be modified.

$>$ Transient simulations were shown to be practical but a database for long-term changes is needed. 52 years of data from 1945 to 1997 need to be reviewed and analyzed for proper use in the models.

Figure 1-1 shows the regional setting of Yucca Mountain. Nye County has installed and monitored pressure and temperature instruments in boreholes UE-25 ONC\#1 and USW NRG-4 (Figure 21) to evaluate long-term pneumatic conditions at strategic depths in the subsurface both in response to fluctuations in atmospheric conditions and in response to other possible disturbances resulting from site characterization activities such as the ESF tunnel construction. Nye County has also installed instruments to measure temperature, pressure, humidity and wind speed within the ESF tunnel to characterize the air being used to ventilate the tunnel that could potentially impact the performance of the repository. Additionally, Nye County collected gas samples from the vadose zone in ONC\#1 to establish background conditions and to evaluate changes in the chemical composition of the gases. Changes in the chemical compositions of the gases in the vadose zone with time may be used to evaluate the impact of the ESF construction and to obtain transport properties of the rock mass at the site. Finally, Nye County is conducting numerical simulations to evaluate factors (including tunnel ventilation) which affect both shortand long-term pneumatic and moisture conditions in the repository host rock.

Nye County has also been evaluating critical new data and information as they become available from the DOE's Yucca Mountain Project studies. In the past year, Nye County has observed water usage in the tunnel and its potential impact on the repository horizon and the scientific investigation results. Some of these communications have resulted in DOE's more focused attention to some of the issues raised 
by Nye County. Specifically, these issues related to the need for more detailed studies in the ESF tunnel, limiting the use of construction water, and enhanced interpretation of the results of the isotope sampling.

Nye County is planning to perform several investigations in the near future to investigate issues that remain significant if funds remain available. These issues are related to the steep gradients in the saturated zone north and west of the site, the potential for dilution in the saturated zone as unsaturated zone moisture enters the saturated zone, the atmospheric and pneumatic boundaries in the Solitario Canyon that might impact the repository performance, and the large-scale transport properties of the fractured formations in both saturated and unsaturated zones. 


\section{INTRODUCTION}

\subsection{PURPOSE AND SCOPE}

The purposes of the investigation reported in this summary document are:

$>$ Identify areas of investigation that need to be addressed by the Yucca Mountain Project (YMP) or that Nye County feels should be given higher priority.

$>$ Investigating key issues related to conceptual design and performance of the repository that can have major impact on human health, safety, and the environment.

This report summarizes the activities that were performed during the period from May 1, 1998 to April 30, 1999. These activities were conducted in support of the Independent Scientific Investigation Program (ISIP) of Nye County at the Yucca Mountain Site (YMS).

The Nye County NWRPO is responsible for protecting the health and safety of the Nye County residents. NWRPO's on-site representative is responsible for designing and implementing the Independent Scientific Investigation Program (ISIP).

The reader is referred to previous reports (NWRPO. 1995; MET, 1995; MET, 1996; MET, 1997. and NWRPO, 1998) for detailed explanation of these specific concerns.

Two boreholes (USW-NRG4 and UE-25 ONC\#1) and the Exploratory Study Facility (ESF) tunnel have been instrumented by Nye County since early 1995. The preliminary data and interpretations presented in this report do not constitute and should not be considered as the official position of Nye County. Also included in this summary report is the use of the data obtained from the Early Warning Drilling Program (EWDP) of Nye County in development of the Saturated Zone modeling of the area of concern.

Nye County has installed and monitored pressure and temperature instruments in boreholes UE-25 ONC\#1 and USW NRG-4 (Figure 1-1) to evaluate long-term pneumatic conditions at strategic depths in the subsurface both in response to fluctuations in atmospheric conditions and in response to other possible disturbances resulting from site characterization activities such as the ESF tunnel construction. Nye County has also installed instruments to measure temperature, pressure, humidity and wind speed within the Exploratory Studies Facility (ESF) and Enhanced Characterization of the Repository Block (ECRB) tunnel to understand the ventilation processes that could potentially impact the performance of the 
repository. Additionally, Nye County has collected gas samples from the vadose zone in ONC\#1 to establish background conditions and to evaluate changes in the chemical composition of the gases. Changes in the chemical compositions of the gases in the vadose zone with time may be used to evaluate the impact of the ESF construction and obtain transport properties of the rock mass at the site. Furthermore, Nye County is conducting numerical simulations to evaluate factors (including tunnel ventilation) which affect both short- and long-term pneumatic and moisture conditions in the repository host rock.

Nye County has also been evaluating critical new data and information as it becomes available from the DOE's Yucca Mountain Project studies. In the past year, Nye County has continued its observation and analyses of the water usage in the ESF and ECRB tunnels to evaluate its potential impact on the repository horizon and the scientific investigation results.

One of the most important aspects of Nye County's investigation in the vicinity of Yucca Mountain was related to numerical modeling and data availability in the saturated zone. Nye County, through its independent scientific investigations, has concluded that the current models, used to evaluate the saturated zone of the Yucca Mountain and vicinity, suffer from lack of data and understanding in several critical geographical areas. The modeling approach is also heading in an inefficient direction. Emphasis and efforts on steady-state simulation of the area in the vicinity of Yucca Mountain are of little use and value in understanding the dynamics of a transient groundwater system or in predicting future impacts. Nye County has been performing simulations using a transient saturated-zone model. This model is being evolved as more data from the EWDP testing become available. Pumping tests have been used to calibrate portions of this model.

Nye County is planning to perform investigations in the near future to investigate issues that remain significant. These issues are related to the steep gradients in the saturated zone north and west of the site, the potential for dilution in the saturated zone as unsaturated zone moisture enters the saturated zone, the atmospheric and pneumatic boundaries in the Solitario Canyon that might impact the repository performance, and the large-scale transport properties of the fractured formations in both saturated and unsaturated zones.

\subsection{SIGNIFICANT FINDINGS}

Several important issues were identified and studied during this period of the investigations:

$>$ The need for alternative repository design investigation was discussed and evaluated during the workshop held by Nye County and Department of Energy. In this workshop, it was realized that the elevated temperature resulted from the decay of radioactive material in the canisters create effects on the repository are extremely complicated to analyze. Issues that 
may be raised as a result of the large-scale elevated rock temperature cannot be confidently addressed. This point was also emphasized in the Expert Elicitation Panel on Repository Design and Performance. The consensus was that the viability of an alternative lowtemperature repository that is readily accessible for an extended period of time should be carefully studied.

$>$ The naturally ventilated design deserves serious consideration, and the additional work needed to evaluate it should be given a high priority during performance confirmation, if not before licensing. This work should include, at a minimum, continued underground and environmental monitoring during repository construction, large-scale natural ventilation experiments, comprehensive simulations of heat and moisture removal, and appropriate tests to validate models.

$>$ Data from ESF and ECRB showed that tunnel instrumentation for environmental and ventilation parameter characterization should be done at various cross-sections. Although ambient conditions are well characterized with the methods used in this investigation, more sophisticated and systematic instrumentation are needed to conduct deterministic studies. Ventilation experiments need to be designed to obtain data at conditions predicted for the repository. The naturally ventilated repository experimentation can be much less costly than the current heated alcove experiment.

$>$ Modeling of the natural ventilation indicated that modification of the A-TOUGH code is necessary to provide capability for the coupled effect of the heat and moisture transfer between the rock and the tunnel air. Although the current A-TOUGH code is fully coupled, variations in eddy diffusivity need to be coupled with the mass and energy flow in the tunnel. The significance of this coupling is not presently known. This is due to lack of experimental data at elevated temperatures around the canisters. In addition, the model needs to be calibrated against other, known cases of mine ventilation and drying.

$>$ Modeling of the saturated zone and incorporation of the preliminary data from the EWDP indicated that the conceptual model of the valley fill deposits needs to be modified in the current DOE models to represent the significant heterogeneity that exists in these deposits. The thickness of these deposits and the proximity of the more conductive units to the ground surface, make the valley fill deposits an important component of the saturated-zone flow system.

$>$ Transient simulations were shown to be practical but a database for long-term changes is needed. 52 years of data from 1945 to 1997 need to be reviewed and analyzed for its proper 
use in the models. This data was entered into a database that needs to be validated and qualified with respect to the representation and accuracy of the information.

$>$ Review of Section 5 of the Yucca Mountain Site Description document identified several critical areas that need further investigation or refinement of data analyses. One of the major inadequacies is the integration of the pneumatic properties of the fractured rocks. The pneumatic properties are not only important in understanding potential pneumatic pathways through the repository host rock, but are of paramount importance in designing a cooler repository. Natural ventilation calculations rely heavily on these properties. Even if a naturally ventilated repository is not decided to be viable, pneumatic properties are important in understanding heat flow through the mountain. None of the numerical studies performed to date address the effect of these properties on heat dissipation and distribution.

\section{MONITORING ONC\#1, NRG-4, ESF TUNNEL, AND ECRB DRIFT}

Monitoring ONC\#1 and NRG-4 was continued as in previous years. At the end of this period. NRG-4 monitoring was decommissioned since it is believed that adequate data have been obtained from this borehole. Monitoring can be resumed at anytime in the future if it is deemed necessary. Analysis of the data from these boreholes is underway and will be incorporated in the numerical simulation of the unsaturated zone with the emphasis on pneumatic pathway and ventilation analysis.

ESF monitoring was continued with the new portable instrument assembly. Several locations in the ESF were surveyed for time periods ranging from a week to several weeks. The ECRB was monitored by this assembly at several stations during boring of the drift. Currently, this system is setup to monitor environmental conditions behind the bulk head. Data are periodically downloaded as access to the ECRB becomes available.

In this reporting period, data from the ESF were obtained from the Yucca Mountain Project (YMP). These data were compared with the observations made with the Nye County instrumentation results. It was determined that in order to accurately evaluate and assess the mass and energy balance in the tunnel, cross-sectional systems such as Nye County has devised are necessary.

The following data were obtained and activities were performed during this period:

\subsection{ONC\#1 MONITORING}

$>$ Temperature, Pressure, and Piezometric Data were retrieved from 5/27/98-5/26/99. 
$>$ The data logger (MDL) was replaced 8/13/98.

$>$ Data were added to the nycoun97.mdb, and stor $97 . \mathrm{mdb}$ databases. These databases are independent of the regional groundwater database.

$>$ PowerPoint files were created for monthly graphs. These graphs are included on the $C D$ that accompanies this report.

$>$ Graphs were converted to GIF files, data files were compressed (zipped) and uploaded to Nye County web site (www.nyecounty.com).

$>$ All piezometric water level graphs were added to existing web pages from beginning of data collection.

$>$ The web page format was revised.

\section{2. $N R G-4$}

$>$ Temperature and Pressure data were retrieved from 5/28/98-1/15/99

$>$ No data were collected from $6 / 27 / 98$ to $7 / 14 / 98$ due to a short in the wires.

$>$ No data were collected between $8 / 13 / 98$ and 9/1/98 due to malfunctioning of the MDL. which was removed and replaced on $8 / 13 / 98$.

$>$ The MDL was removed on 1/15/99 at 1:08 PM.

$>$ Data were added to the nycoun97.mdb, stor97.mdb databases.

$>$ PowerPoint files were created for monthly graphs.

Graphs were converted to GIF files, data files zipped and uploaded to Nye County web site.

$>$ The web page format was revised.

\subsection{ECRB}

$>$ Temperature, Pressure, Relative Humidity, Volumetric Water Content, and Air Velocity were measured at various locations.

$>$ Data were retrieved from $6 / 30 / 98$ to $12 / 22 / 98$. 
$>$ Monitoring began at station $2+85$ and ended at station $25+72$.

$>$ Time-Domain Reflectometers (TDR) were removed from the wall on 8/27/98; therefore, no further volumetric water content data were collected after that date. The TDR's were removed because the rock dried quickly beyond the sensitive range of the TDR. It is expected that when USGS data from psychrometric and heat-dissipation probe water content measurements become available, analysis of the data can be completed.

$>$ Hotwire \#3 was removed on $8 / 4 / 98$ for calibration and repair purposes. Therefore, velocity measurements for this probe are not available.

Since air is expected to be almost stagnant in the ECRB during the sealed period, air velocity measurements were discontinued.

$>$ Power Source caused fluctuation in Campbell readings between 9/6/98-9/10/98.

$>$ Ventilation in the tunnel was turned off between $12 / 18 / 98-21 / 21 / 98$; therefore, minimal air velocity data are available for that period of time.

$>$ Data were added to the stor_esf.mdb database which is in parallel to the surface-based borehole databases.

$>$ All graphs were stored in graph.xls.

$>$ PowerPoint files were created for each month.

$>$ Graphs were converted to GIF files and were uploaded to the Nye County web site.

$>$ The web page format was revised.

\subsection{Results of Monitoring}

This section briefly describes the results of monitoring pressure and temperature in UE-25 ONC\#1 and USW NRG-4. A more comprehensive presentation of the results of monitoring is posted on a monthly basis on the Internet (www.nyecounty.com). The ONC\#1 borehole was drilled and completed in December 1994. Both ONC\#1 and NRG-4 boreholes were instrumented to support the following data collection activities:

$>$ To monitor the long-term variation of pressure and temperature in hydrogeologic units that may be impacted by the construction of the ESF. 
$>$ To perform vacuum and/or injection pneumatic testing to evaluate the horizontal and, to some extent , vertical pneumatic conductivity values of the hydrogeologic units packed off by the Westbay Instruments.

$>$ To sample intervals isolated by packers for environmental isotopes to evaluate the residence time of the gases in the hydrogeologic formations.

The Nye County borehole locations were selected primarily to establish baseline conditions before penetration of the repository host rock by the ESF tunnel and to monitor the effects of the mine ventilation system used in the ESF tunnel on the ambient pneumatic and moisture conditions of the unsaturated zone in the vicinity of the north and south ramps of the ESF tunnel. UE-25 ONC\#1 is situated southeast of the repository block and is in the path of the future South Ramp of the ESF tunnel. It was also strategically located to be along the main trace of the Bow Ridge Fault system and close enough to DOE's C Well Complex (approximately 800 meters) to serve as a monitoring well during aquifer testing. It was drilled by Nye County in late 1994 and early 1995 using dual wall reverse circulation technology to demonstrate an alternative drilling and sampling method (NWRPO, 1995).

USW NRG-4 is located northeast of the repository block and is situated about $1100 \mathrm{~m}$ from the North Ramp (NR) portal of the ESF tunnel. It was previously drilled by DOE. The ESF tunnel passed within approximately 15 meters of USW NRG-4 in the middle of June 1995. The effects of the tunnel excavation on pneumatic conditions in this instrumented borehole, as well as in UE-25 ONC\#1, have been discussed in the previous annual reports (NWRPO, 1998, 1995).

Nye County instrumented UE-25 ONC\#1 and USW NRG-4 in early 1995 with Westbay Corporation's MP55 system. The MP-55 is a multilevel monitoring system that consists of access casing with multiple ports or valves that can be opened to the formation. A multilevel packer system integrated into the access tube serves to isolate access ports and retrievable MOSDAX temperature/pressure measurement probes that connect to these access ports. An above ground data logger is used to store data acquired by the temperature/pressure probes. A complete description of this downhole monitoring system and installation procedures in these boreholes is presented in NWRPO (1995).

Fifteen downhole packers were used to isolate major stratigraphic units, a fault zone, and two isolated zones below the water table in UE-25 ONC\#1. Figure 2-1 shows the location of the 15 packers and 31 measurement ports in relation to stratigraphic units, the Bow Ridge fault zone, and the water table. MOSDAX temperature/sensor probes were installed in 9 of the 31 measurement ports available. It should be noted that the two bottom-most probes in UE-25 ONC\#1 are situated below the water table and are monitoring the piezometric potential. 
Seven downhole packers and 7 measurement ports were strategically installed in major stratigraphic units in USW NRG-4 as shown in Figure 2-1. MOSDAX temperature/sensor probes were installed in all 7 measurement ports.

The pressure and temperature in UE-25 ONC\#1 and USW NRG-4 have been monitored since April 1995. Temperatures reported for all downhole instruments are fairly stable with occasional deviations from the norm. The atmospheric probe (Probe 0 ) in each borehole records a wide range of daily and seasonal temperature fluctuations typical of a desert environment. Comparison of the temperature data from atmospheric probes in USW NRG-4 and UE-25 ONC\#1 indicates very consistent atmospheric temperature patterns at the two borehole sites.

Pressure fluctuations with time for UE-25 ONC\#1 and USW NRG-4 show that pressure responses exhibit trends versus depth that are expected in layered geologic media. That is, there is a general dampening of the magnitude as well as an increasing timelag in the peaks and valleys of barometric pressure fluctuations as depth increases.

Two of the probes in UE-25 ONC\#1 (Probes 8 and 9) are below the water table. These probes monitor variation of piezometric level with time.

Nye County has also received data from unsaturated zone boreholes monitored by U.S. Geological Survey's. These data were analyzed and graphed to compare the data collected by the Yucca Mountain Project (U.S. Geological Survey) with those collected by Nye County. These graphs show that, despite the significant difference in the data collection techniques, there is a close agreement between the averages of the data. The slight differences in the trends and magnitudes are expected due to the position of the boreholes with respect to the natural and man-made boundary conditions.

\section{GAS SAMPLING FROM ONC\#1}

The purpose of the gas sampling is to:

Estimate the ages of the gases in the vadose zone in ONC \#1 and their relationship with the ages of the water obtained from other boreholes at Yucca Mountain that could help evaluate the percolation and recharge at the site.

$>$ Understand the transport mechanisms governing gaseous migration in the vadose zone at this site.

$>$ Evaluate the effect of tunneling on the repository horizon. 
The South Portal of the Exploratory Studies Facility (ESF) tunnel is near ONC\#1 . ESF tunnel broke through at the South Portal on May 20, 1997. The tunnel is a boundary condition for temperature, pressure, humidity, and environmental isotopes. Diurnal variations pressure in the tunnel correspond with the outside atmospheric barometric fluctuations. Pressure and temperature responses that have been observed in various unsaturated zone boreholes, including ONC\#1, may be attributed to the existence of the tunnel. The gas sampling is designed to potentially detect existing gaseous chemicals in the atmospheric air introduced into the repository horizon through the tunnel

Preliminary results indicated that the sampling method used for obtaining gas samples from ONC $\# 1$ is very efficient and produces results that seem to be comparable with results of other UZ sampling techniques that have been used at Yucca Mountain.

\section{EVALUATION OF SATURATED ZONES HYDROLOGY}

\subsection{REGIONAL HYDROGEOLOGICAL MODELING}

This section presents an overview of Nye County's Fiscal Year 1999 activities related to the hydrogeologic conditions of the region surrounding Yucca Mountain. A thorough understanding of the groundwater conditions of the region is a prerequisite to accurately predicting the long-term performance and impacts of siting a high-level waste repository at Yucca Mountain. Nye County is particularly interested in the losses and damages that might result from locating a repository at Yucca Mountain. Although the major effort for understanding the saturated zone environment of Yucca Mountain and the vicinity is funded under a separate grant (EWDP), data and outcome of those investigations are used in the present investigations.

In the Department of Energy's evaluations of the regional groundwater conditions, an emphasis has been placed on the use of numerical models that simulate the hydrologic processes at work so groundwater flow paths and travel times can be predicted.

Nye County recognizes the need for these modeling efforts and believes that a well-calibrated flow model of the region would provide a powerful tool for use in water resources planning and management. The "ideal" model would provide an accurate predictive capability for managing the County's water development over the coming decades. Such a model would be able to accurately simulate the presence of existing and future contaminant sources and the locations and duration of groundwater withdrawals. The results of models that have been completed to date, while encouraging, indicate that there is still considerable uncertainty and that further refinement is needed before regional groundwater models can provide such tools. 
In parallel with the Department of Energy's efforts, Nye County has been conducting modeling of the saturated zone in a different fashion to evaluate the concerns outlined above. Nye County is developing independent numerical models of the groundwater flow regime in the vicinity of Yucca Mountain. Currently, these models are merely tools to evaluate the gaps in data and to provide means of estimating potential responses of a portion of the system to various changes in the boundary conditions in the system. The modeled area comprises the western most portions of the Death Valley flow system. A large gap in subsurface hydrogeologic data existed, prior to drilling of the EWDP boreholes, between the southern limit of Yucca Mountain and the Amargosa Valley. There is a lack of aquifer test data, and information on aquifers present, their extent, and their hydraulic properties. Other data gaps are located between the proposed repository site and the nearest populated areas in Oasis Valley and Pahrump Valley.

\subsubsection{PROCEDURES FOR SATURATED-ZONE MODEL SETUP}

In previous attempts, the entire Death Valley groundwater model of D'Agnese et. al., 1997, was converted to a four layer, three-dimensional model using A-T2VOC. A-T2VOC requires time-varying solutions to arrive at steady-state conditions equivalent to MODFLOWP, which uses a zero storage change to force steady-state calculations. In order to establish a steady-state condition that was comparable to that of D'Agnese's model, an initial condition was arbitrarily chosen that represented condition of 1947-1960 average. Theoretically, the two codes should arrive at the same steady-state solution regardless of the initial conditions. However, in the process of running A-T2VOC, it was realized that certain parts of the modeled domain have erroneous hydraulic conductivity values such that achievement of a steady-state condition would require very long-term solutions. Given that the initial condition was so close to the steady-state solution, it was realized that the calibration of the steady-state model could not be valid, otherwise, the steady-state solution would have been achieved within 100 years. Search for data to calibrate a transient model revealed a severe deficiency in data for most of the Death Valley Region. Therefore, as was presented at the Devil's Hole Workshop of 1998, it was decided that basins within the Death Valley Groundwater system be isolated and simulated separately. The first two candidates were the Amargosa Valley/Yucca Mountain (AVYM) system and Pahrump Basin. Because of the need of the EWDP program of Nye County, the AVYM was given priority.

In this second attempt, it was decided to proceed with caution and systematically calibrate a transient model in areas where adequate data were available. The following procedure was devised and successful in carrying out the tasks. The model that is presented as a result of this effort by no means qualifies as "calibrated". It is a conceptual numerical model that is being used to evaluate the areas where most data is needed and to verify and test alternative conceptual models that are developed as a result of EWDP drilling.

Figure 4.1 shows the location of the AVYM model in relation to the USGS model. 


\subsubsection{STEADY STATE}

\section{Verification simulation with USGS model:}

The first task was to verify that the electronic files that were provided by USGS produced the same results using the version of MODFLOWP that was acquired for Nye County. The results were identical.

\section{Simulations of AVYM model using constant head boundaries:}

Because only a portion of the Death Valley Region was being modeled, it was necessary to verify that the results of the portion of the USGS model, corresponding to the AVYM model, could produce the same results. A simple task was to set the potentiometric heads to constant values obtained from the USGS model. The results were again identical.

\section{Converting all boundary nodes of the AVYM to general head boundaries:}

General head boundaries (GHB) are nodes that are given a flux value that is determined by an assigned fictitious head outside the modeled domain. The value of the flux is then calibrated to produce the desired head values within the modeled domain. In steady-state simulations, this is the same as a constant head boundary described above. However, in transient simulations, constant head boundaries cannot be used because the fluxes across the boundary change with time. For this reason, a GHB provides the flexibility to calibrate a transient model. This step was performed to verify that by changing the constant head to GHB the original USGS values could be reproduced. The results were identical, as expected.

\subsubsection{TRANSIENT}

Transient simulations require potentiometric head data for the period of simulation. At the time of these simulations, Data were available from 1926 through 1997. Figure 4.2 shows an average water-level contour map for this period. The initial condition for the transient simulations was set at the average of the conditions between 1947and 1960. The averaging was performed because none of the particular years in that period had enough wells to define a representative potentiometric map. Even with the entire 71 year record, there are no water-level data for a major portion of the modeled region. For this reason, average potentiometric distribution for the area were computed for each 10-year interval following 1960 . Therefore, there were three different calibration times for when the model potentiometric levels. (1970, 1980, and 1990). 
For each period, a nearest neighbor method was used to interpolate the observed potentiometric levels. Obviously, as one moves away from the observation points (wells), the error of estimation increases. Therefore, the model results are only reasonable for areas where there are ample observation points. There are very few observation wells that are deeper than 1000 feet. Therefore, the confidence in the predicted results for layers two and three of the model is low. Also, because there is little vertical control, the calibrated hydraulic parameters are good only for the horizontal direction. Because the adjustment of the vertical hydraulic conductivity values affect the prediction of the potentiometric surfaces, the horizontal hydraulic parameters are also subject to uncertainty. Currently, Nye County is conducting large-scale pumping tests that will be used to provide estimates of the horizontal aquifer properties for parts of the area. Fixing the horizontal parameters will aid in estimating the local vertical hydraulic parameters with more certainty.

The EWDP data help fill a significant gap in the data downgradient of Yucca Mountain. The matching of data from these wells has moved the 700-m potentiometric contour predicted by the USGS substantially to the north. It is expected that new data planned to be collected over the next few years will substantially change the conceptual hydrogeologic model of the Amargosa Valley.

One of the significant differences between the pre-EWDP conceptual model and the present model is the areal extent and hydraulic characteristic of the alluvial valleys. The alluvial valleys were originally conceived to be filled with relatively uniform material, consisting mostly of alluvial and colluvial origin. During drilling and as a result of the modeling effort, it became evident that some of the alluvial filled channels are carved into a much less permeable material. This material consists of ash fall and ash flow tuffs, marsh and lacustrine deposits, with occasional extrusive volcanic deposits. The sequence of deposition has been complex. At times the valleys may have been covered by relatively thick deposits of lacustrine and marsh deposits. These deposits were then eroded away by stream-flow activities that resulted in substantial shelf areas with fine-grained and low permeability material. Alluvial deposits have been laid down in the middle of these valleys and are thickest in the center. Off course, Cenozoic tectonic activities have further complicated the sequences of deposition. Faults have cut through some of these low permeability materials and appear to have provided conduits for vertical flow of groundwater from deepseated carbonate aquifers.

The existence of high permeability material in the middle of these valleys is evident by the shape of the potentiometric surface maps. Steep gradients are often observed near the edges of these alluvial deposits where surficial materials that overlie the low permeability materials are relatively thin.

\subsubsection{AMARGOSA VALLEY FLOW SYSTEM BOUNDARIES}

The boundaries of the model were set to incorporate the entire Amargosa Valley and Fourtymile Wash basins. The geographical boundaries are arbitrarily set at the ground-water basin boundaries. There 
are no special characteristics assumed for these boundaries. Figure 4.4 shows a general outline of the model boundaries and the physiographic features that it encompasses.

\subsubsection{STEADY STATE VERSUS TRANSIENT CONDITIONS}

At the Devil's Hole workshops (1998, 1999), the issue of steady-state versus transient conditions was identified by Nye County. In essence, this issue stems from the implied assumption in some of the models that steady-state conditions prevail across the model domain. This assumption may be in error as climatic conditions and the development of ground water by man have significantly altered the hydrologic regime. The period over which these changes have occurred represent transient conditions rather than steady-state.

True steady-state conditions probably last occurred during the Pleistocene. During Pleistocene time, more precipitation resulted in more runoff and more recharge. As a result, there were large lakes present in Pahrump Valley, Death Valley, and smaller lakes in the Amargosa Flat area. The Pleistocene environment over much of the Amargosa Desert basin was marshland with ground water at or near the land surface over much larger areas than today. As more arid conditions prevailed, corresponding declines in water levels and spring discharge rates occurred. These changes lasted for thousands of years and, as basins became more isolated, these changes created more pronounced transient conditions. This is because the near-surface aquifers, especially the high permeability volcanic aquifers, have responded more rapidly to the draught than the deeper and more confined Paleozoic aquifers. It is suspected that some of the deeper aquifers are still under the influence of the late-Pleistocene recharge that occurred in.

\subsubsection{CALIBRATION}

Nye County notes that none of the models have been shown to meet the calibration requirements under ASTM Standard D 5490-93 (American Society for Testing Materials, 1994, Standard Guide for Comparing Ground-Water Flow Model Simulations to Site-Specific Information, Philadelphia, PA). Nye County has been proceeding with calibration efforts that involve particular model nodes for which data become available through the EWDP effort. Each AVYM model node for which data becomes available is modeled separately using a much finer mesh to reproduce the results of a pumping test or a long-term monitoring period. Once these nodes are calibrated satisfactorily, their equivalent hydraulic properties are assigned to the appropriate AVYM nodes. Using this procedure, the model is considered to be piecewise calibrated. 


\section{ALTERNATIVE REPOSITORY DESIGN}

\subsection{TUNNEL INSTRUMENTATION AND DATA}

Simulation of natural ventilation was continued during this year. The previous axi-symetric model was converted to a three-dimensional model (Figure 5.1). The unsaturated zone mesh used to simulate Yucca Mountain (LBL, 1997) was used as a basis for this conversion. This mesh was modified to reduce computational demands. A series of tunnel nodes was created to simulate the ESF and ECRB. First a mesh without fractured rock elements was created with equivalent porous media properties assigned to the blocks involved in the simulation. Simulations with discrete fractures are underway.

\subsection{ATMOSPHERIC MONITORING}

Nye County installed instruments to measure temperature, pressure, humidity and wind speed within the ESF tunnel to characterize the air being used to ventilate the tunnel which could potentially impact the performance of the repository. An underground climatological monitoring station was installed in August 1995 behind the ESF tunnel boring machine (TBM) to measure the temperature, pressure, and relative humidity of ventilation air. This monitoring station moved with the tumnel boring machine frame. As the TBM broke through at the South Portal on May 20th, 1997 the instrumentation was disassembled and monitoring was discontinued. In November 1997 another monitoring station was setup along the wall of the ESF tunnel approximately located at Station 35+63, near Niche 1. In addition to temperature, pressure and relative humidity, an anemometer was used to measure wind velocity in the tunnel. Also, soil moisture probes were installed at two locations in the rock along the wall of the tunnel at this location. Data were collected at this monitoring station for one month and were then analyzed to determine how atmospheric conditions in the tunnel may be affected by ventilation. Variations in the water content of the rock were also observed and these data were analyzed in relation to changes in atmospheric conditions in the tunnel. In December 1997 construction commenced on the ECRB tunnel. This tunnel runs in approximately east-west direction and traverses the ESF main loop at ESF Station 31+00. A climatological monitoring station was set up in the ECRB in May 1998 at ECRB Station 1+00. This station was designed to be easily disassembled so it could be relocated to other positions within the ECRB. As the TBM bored through the rock during the construction of the ECRB, Nye County relocated the monitoring station approximately every 500 feet as the. Results of Nye County's monitoring in the ESF are presented in a series of graphs in MET (1997).

\section{DATABASE MANAGEMENT}

Nye County has developed a hydrogeologic database for the Death Valley Hydrologic Basin that includes information about all the wells, springs, and other pertinent hydrologic features in the basin 
(referred to as the Nye County Database or NCD in this report). Nye County has transferred existing databases and geographical information systems (GIS), into the NCD to minimize duplication. Attempts were made to coordinate this effort with the U.S. Geological Surveys efforts, however, coordination with the YMP specialists has not been possible. The majority of the data transferred to the NCD were D'Agnese, et. al. (1997), DOE (1997), and the Technical Data Management Geographical Information Systems of DOE (1997). Additional data from the Nevada State Engineers Office and various published reports were entered into NCD and integrated with the GIS.

The NCD uses SATURN GEIS ${ }^{\otimes}$ which is a Microsoft ${ }^{\otimes}$ Access $^{\otimes}$ based software system. The NCD SATURN GEIS does not require Microsoft ${ }^{\otimes}$ Access $^{\otimes}$ to query the data. It allows querying the well and spring information based on sub-basins, groups of wells and springs, regional grouping, ranges of dates, types, and categories of data. Once a query is completed, the selected range of data can be visualized in two- or three-dimensional graphs and renderings. Geologic cross-sections, fence diagrams, and models can be visualized in either still or animated views as desired. The NCD is currently being used to prepare the inputs for the Nye County regional groundwater model.

The attached media (compact disk) Nycoun98.mdb contains pressure and temperature data for UE-25 ONC\#1 and USW NRG4 and data continuous monitoring of the ESF climatic conditions during ESF construction. This database can be opened directly with Access ${ }^{\otimes}$ version 2.0. Data access and sorting can be done with user-friendly menus. Tuneldata.mdb contains temperature, pressure, humidity, and air velocity data for various locations within the ESF and ECRB after November 1997. This database can be viewed using the Access ${ }^{\oplus}$ program.

The file modelUTM.mdb contains a Saturn database with water level data. This database is preliminary. Additional data are being added, and the database is undergoing quality assurance review.

The geographic information system activity has been limited to transfer of the coverages from the DOE Technical Data Management GIS into the SATURN database. No modification of the original graphic files has been made. Several hydrological and demographic coverages have been regrouped and reorganized into a SATURN compatible electronic file structure. The Nye County GIS files are not included in the media because the compilation and integration with the ongoing effort under the Oversight Program of Nye County has not been completed yet.

\section{SUMMARY REPORT OF PROCEEDINGS of the WORKSHOP ON VENTILATED REPOSITORY DESIGN}

On December 1 \& 2, 1998 the Nye County Nuclear Waste Repository Project Office, in cooperation with the U.S. Department of Energy, Yucca Mountain Site Characterization Office, sponsored 
a workshop on alternative repository designs, with an emphasis on ventilation to optimize repository design and operation.

Studies conducted by the Nye County NWRPO over several years suggest that Yucca Mountain provides unique opportunity for designing and operating a naturally-ventiled repository. A significant drying and cooling effect, removing substantial amounts of moisture and heat from the rock surface in the ESF tunnel has been observed in these studies. This would, substantially limit water from contacting the surfaces of the waste packages, and thus minimizing premature failure of the waste package that could cause accelerated migration of the radionuclides to the accessible environment. The reduction in heat would facilitate operation of the repository, increase the life of the waste package, and potentially reduce the acerage requirement for the waste disposal. The purpose of the workshop was to discuss these phenomena, and to examine alternative repository designs which allow for such ventilation.

The workshop grew out of discussions between representatives from the NWRPO and Lake Barrett, Director of DOE's Office of Civilian Radioactive Waste Management. Although not a co-sponsor, DOE cooperated with Nye County in organizing and scheduling the workshop, reviewing and offering suggestions for the agenda, soliciting presenters and panel members, and encouraging attendance. Paul Harrington of the Yucca Mountain Site Characterization Office was the principal point of contact within DOE.

The workshop objectives were to:

1) develop an understanding of a naturally ventilated repository design

2) compare such an approach to the DOE Base Case Design for its Viability Assessment, along with current alternatives being considered for the License Application design

3) explore, at least in a preliminary sense, any engineering or geotechnical constraints on longterm natural ventilation

4) identify design or operational alternatives which should be avoided so as not to preclude the feasibility of natural ventilation.

5) discuss additional data and analyses that will be necessary before a final decision on longterm ventilation can be reached, and

6) determine the range of appropriate studies and tests that should be conducted to collect the necessary data. 
In addition to Nye County and DOE, representatives from DOE's M\&O, the Nuclear Waste Technical Review Board, the NRC. The NRC's Advisory Committee on Nuclear Waste, the State of Nevada and several Nevada local governments attended and participated in the workshop. Prominent, nonprogram scientists also attended and contributed valuable insights to the discussion.

The workshop focused on technical issues. While there was some discussion, particularly during the wrap-up at the end of the workshop, of legal and regulatory questions, such as whether the current language of the Nuclear Waste Policy Act and the NRC regulations allow for anything other than a fully "closed" repository, there was fairly a general agreement that the focus should remain on the scientific and engineering aspects of a ventilated repository. If the conclusion is reached, after the necessary further studies and analyses, that ventilation, either natural or induced, would indeed optimize repository performance, the statutory and regulatory issues would then best be addressed in another forum.

Alf Wikjord, a performance assessment expert from Atomic Energy Canada Limited on loan to DOE's Yucca Mountain Site Characterization Office, led off the first day with a useful and interesting discussion of general principals of performance assessment, and how the Canadian program is approaching the problem. Discussion then turned to the current DOE design work, and various analyses of the impact of ventilation on repository performance.

\subsection{DOE DESIGN ALTERNATIVES}

The DOE Viability Assessment reference repository design, along with alternative designs currently being evaluated, was provided by Dan McKenzie, the DOE M\&O Manager of Repository Subsurface Design.

The current design addresses several primary requirements with respect to ventilation. Under the NRC regulations still in place the ventilation system must control the transport and release of radionuclides and assure continued functioning during the operational life of the repository, both under normal and accident conditions. Ventilation of emplacement and development operations must be separated. Applicable provisions of $30 \mathrm{CFR}$ Part 57 must be complied with, and the system must allow for retrieval of the entire waste inventory should that become necessary. In addition, the ventilation design must meet the requirements of 29 CFR 1910 and 1926.

The current reference design envisions that emplacement drifts can be continuously cooled, or allowed to heat up and be cooled only when necessary for equipment and/or personnel access. A very low air flow will be used in the drifts after emplacement during the pre-closure stage, which does not provide significant cooling effect. Thus the emplacement drifts must be cooled by induced ventilation if access is necessary. Continuous cooling has been evaluated, but to date the M\&O has not seen any compelling 
arguments that its benefits outweigh the costs involved. Also, no experimental studies has been performed or planned to confirm and verify the performance of the proposed design.

The DOE's current plans call for the repository to eventually be closed and sealed after a longterm period (as long as 300 years) of performance confirmation., to eventually be closed and sealed. Several alternative designs and design features are under active consideration, including continuous postclosure ventilation.

The post-closure ventilation alternative involves the arrangement of the underground facility to allow it to be left open to the atmosphere after all human operations are terminated. The natural ventilation, driven initially by the waste heat and later by the pressure differential created by the elevation differences of the openings, would remove moisture and lower temperatures in the emplacement areas of the repository, resulting in reduced corrosion rates caused by a drier waste package environment.

The $\mathrm{M} \& \mathrm{O}$ has identified several potential disadvantages of the post-closure ventilation alternative. They include licensing concerns, increased potential for human intrusion, increased potential for surface water to enter the facility through open shafts and ramps, potential for the escape of gaseous radionuclides, and uncertainty regarding the longevity of the underground openings, particularly the shafts, ramps, and main tunnels.

Mr. McKenzie summarized by noting that, while the current regulatory structure may preclude adopting the post-closure ventilation approach at this time, it will continue to be studied. Significantly, nothing in the reference pre-closure design would preclude subsequent adoption of the facility to incorporate post-closure ventilation. However, no specific plans were presented in adopting a design that would optimize a naturally-ventilated repository.

As indicated above, it was generally agreed that this workshop was not the proper forum to address the existing licensing regulations, which in the view of the M\&O appear to require sealing and closure of the facility.

\subsection{HYDROLOGIC IMPACTS OF A NATURALLY VENTILATED REPOSITORY}

The concept of a naturally ventilated repository arises out of work performed by Dr. Parviz Montazer of Multimedia Environmental Technology, Inc., principal hydrogeological contractor to the Nye County NWRPO. Dr. Montazer presented the results of his work to date on the hydrologic impacts of natural ventilation. 
Observations and continuous monitoring of temperature, pressure and humidity in the ESF have indicated that there is substantial heat and moisture loss from the rock as a result of air flow. Indications are that, with sufficient ventilation, host rock temperatures may be kept below $30^{\circ} \mathrm{C}\left(86^{\circ} \mathrm{F}\right)$, and the rock face may remain essentially dry for up to 10,000 years. While these observations and simulations are ongoing, and thus the conclusions based on them are preliminary, nevertheless certain advantages, as well as disadvantages, of natural ventilation appear.

The advantages of natural ventilation include:

A cooler repository ( host rock temperatures less than $30 \mathrm{C}$ )

$>$ An essentially dry. repository environment for at least 1000 years and possibly as much as 10,000 years.

$>$ Reduced acreage requirements, with perhaps as little as $1 / 4$ of the present space required for emplacement of the waste

$>$ Significantly reduced uncertainty through passive control of the engineered barrier environment

$>$ The drift faces could potentially be "self healing" through fracture filling

The repository would be accessible for future generations should it be desirable to retrieve all or some of the spent fuel (this is recognized as primarily a policy, rather than a technical consideration)

$>$ There would be less reliance on the integrity of the waste package to provide waste isolation

$>$ Any potential seismic damages would be repairable

$>$ Any rise in the water table could be controlled through the provision of a drainage system

There are also recognized disadvantages, or concerns, which appertain to the naturally ventilated repository concept. They include:

$>$ Increased potential for human and other biological intrusions

$>$ Uncertainty with respect to long term stability of the openings

$>$ Increased potential for atmospheric emissions, both gaseous and particulate matter

$>$ Possible adverse impacts in the event of volcanic or hydrothermal events 
$>$ Unknown potential socioconomic impacts.

With respect to the advantages of natural ventilation, the current model used by Dr. Montazer indicates that the packing density of the waste canisters could be increased by four times, translating into significantly reduced acerage devoted to the repository, and thus less tunnel and drift construction. Performance under DOE's reference design cannot at this time be verified with a high degree of confidence. Experience with the long-term effects of heat and humidity on the host rock and canisters is limited to the last 50 years or so. But we have much experience with corrosion and rock stability at ambient temperatures in other locations, literally over millennia. Additionally, concrete liners would not be required, thus reducing geochemical uncertainty.

Some of the concerns can be addressed with further work, in Dr. Montazer's view. Many manmade and natural openings throughout the world have remained open for thousands of years. Engineering designs such as rubble back fill or concrete lining of the shafts could increase stability. Nevertheless, remote monitoring may be required, and plans for remedial measures may need to be in place. Multiple barrier cross bars and rubble zones or similar features can effectively deter unsuspecting intruders. Intelligent, determined intruders will not be stopped by any design. The inventory of gaseous radionuclides is negligible compared to the potential for atmospheric dilution, and should not be a limiting factor. Particulate emissions can be trapped without the need for filters by providing velocity-reducing cavities to deposit particulate matter.

The naturally ventilated design deserves serious consideration, and the additional work need to evaluate it should be given a high priority during performance confirmation, if not before licensing. This work should include, at a minimum, continued underground and environmental monitoring during repository construction, large-scale natural ventilation experiments, comprehensive simulations of heat and moisture removal, and appropriate tests to validate the models used.

\section{REFERENCES}

Multimedia Environmental Technology, Inc., 1995, Interim Report On Results Of Instrumentation And Monitoring Of UE-25 ONC\#1 And USW NRG-4 Boreholes, Yucca Mountain, Nevada, Nye County Nuclear Waste Repository Office, Nye County, Nevada.

Multimedia Environmental Technology, Inc., October 1996, Annual Report of the Nye County Nuclear Waste Repository Project Office Independent Scientific Investigations Program, Nye County Nuclear Waste Repository Office, Nye County, Nevada.

Multimedia Environmental Technology, Inc., February 1997, Results of First Gas Sampling from ONC\#1, October 1996, Nye County Nuclear Waste Repository Office, Nye County, Nevada. 
Multimedia Environmental Technology, Inc., May 1997, Summary Annual Report May 1996 April 1997 Nye County Nuclear Waste Repository Project Office Independent Scientific Investigations Program, Nye County Nuclear Waste Repository Office, Nye County, Nevada.

Multimedia Environmental Technology, Inc., November 1997, Results of Gas Sampling from ONC\#1, June 1997, Nye County Nuclear Waste Repository Office, Nye County, Nevada.

Montazer, Parviz and Stellavato, Nick, 1996, Simulation and observation of ESF tunnel effects on barometric conditions, International High-Level Radioactive Waste Conference, April1996, Las Vegas, Nevada.

Montazer, Parviz and Stellavato, Nick, 1996, Moisture removal from the repository by ventilation and impacts on design, International High-Level Radioactive Waste Conference, April1996, Las Vegas, Nevada.

Nye County Nuclear Waste Repository Project Office, Independent Scientific Investigations Program, 1998, GRANT DE-FG08-96NV12027, Summary Annual Report - May 1997 - April 1998, July 1998

Stellavato, N., 1996, Borehole UE-25 ONC\#1 Drilling at Yucca Mountain, Nevada: High Level Radioactive Waste Management, Proc. Seventh Annual International Conference, Las Vegas, Nevada, April 29-May 3, 1996, p. 166-7.

Stellavato, N., Sims, S., Perry, J., Housel, M., Moyer, J., and McMaster, L., 1995, Borehole UE25 ONC\#1 and USW NRG-4 Drilling and Instrumentation Report, Yucca Mountain, Nevada: Nye County Nuclear Waste Repository Project Office Rpt., 9/1/95. 


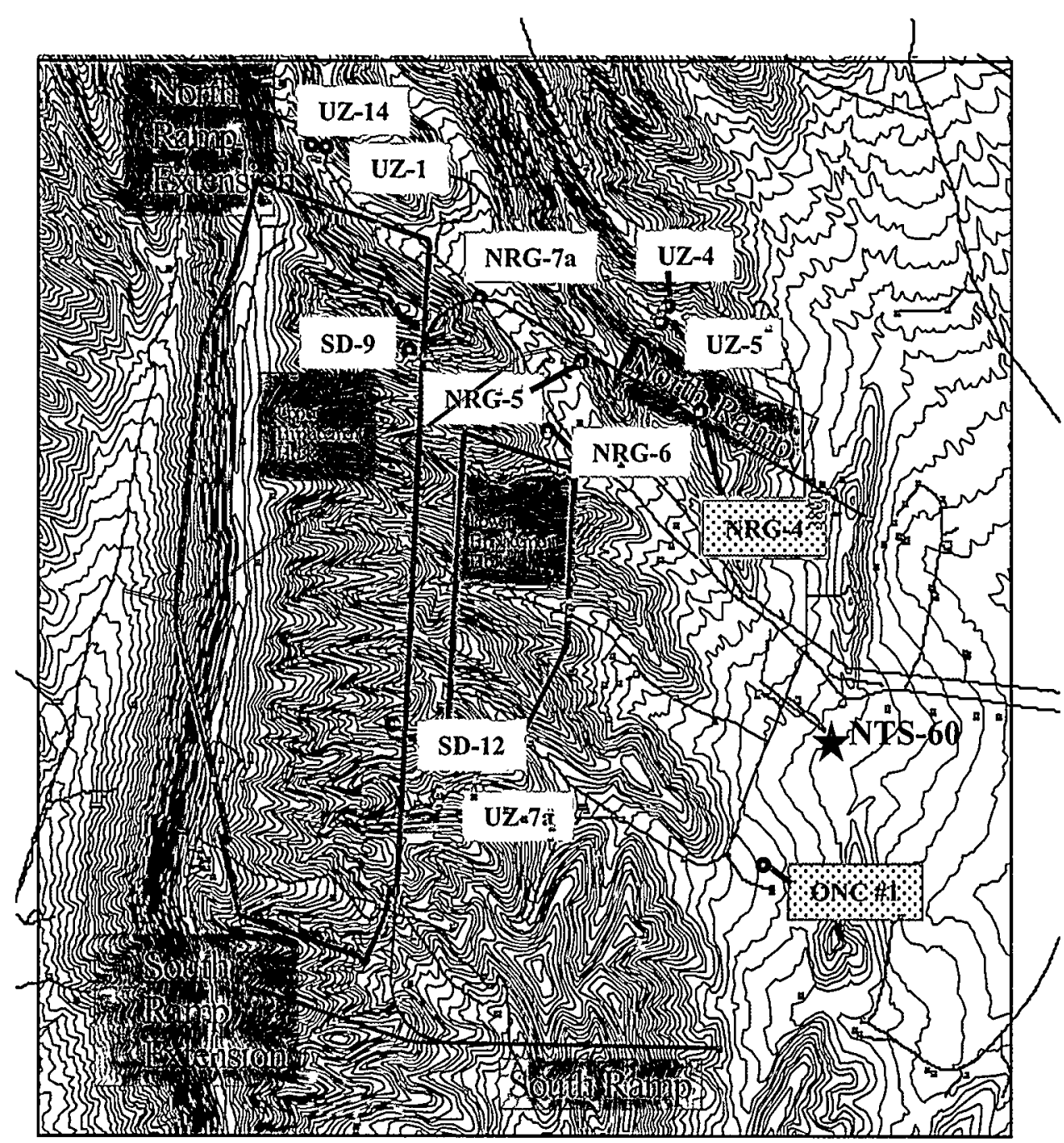

\section{EXPLANATION}

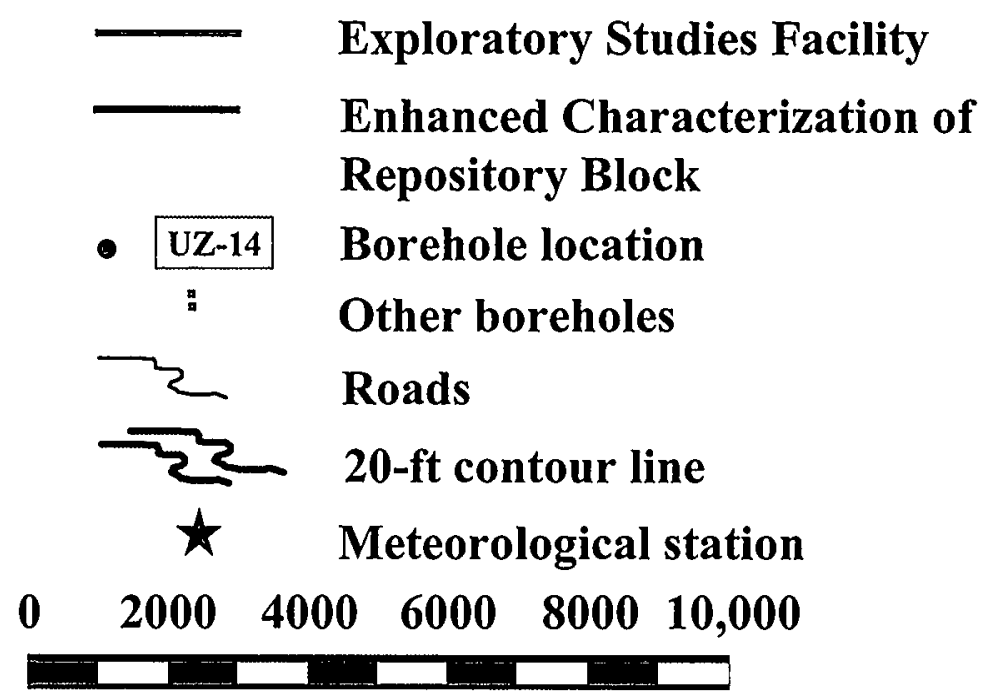

SCALE

Feet

Figure 1-1 Topography, location of selected boreholes, ESF centerline, and ECRB at Yucca Mountain Site. 


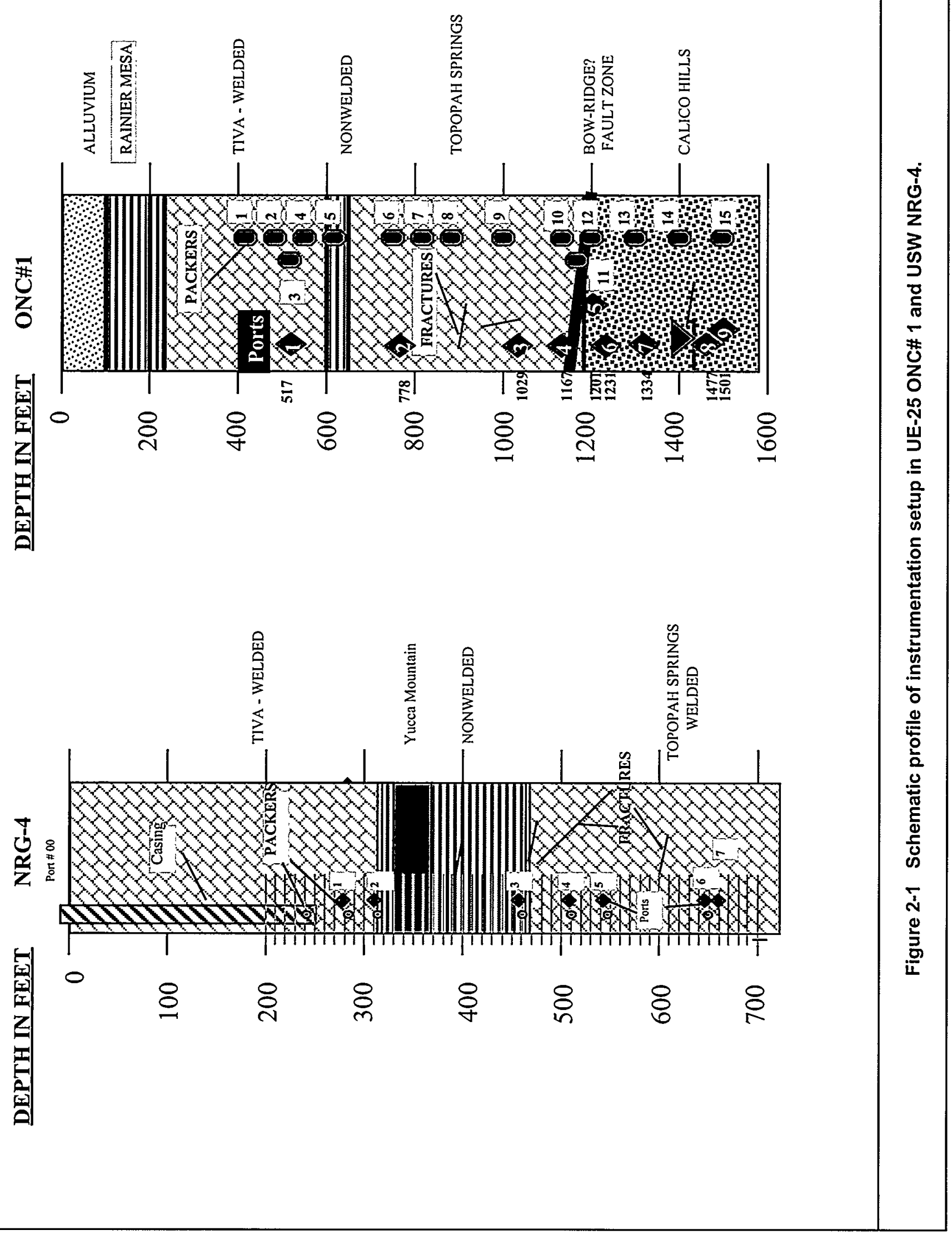




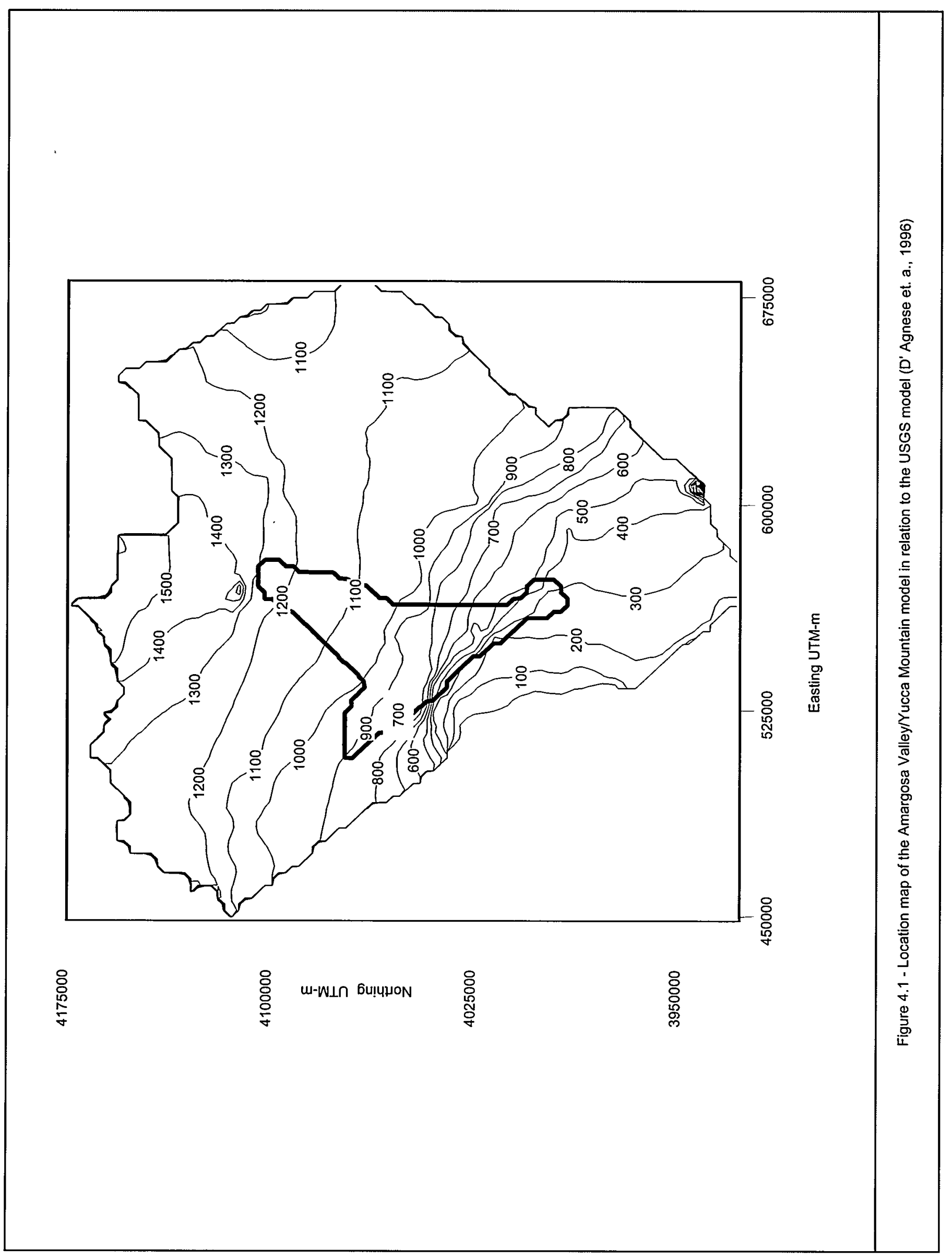




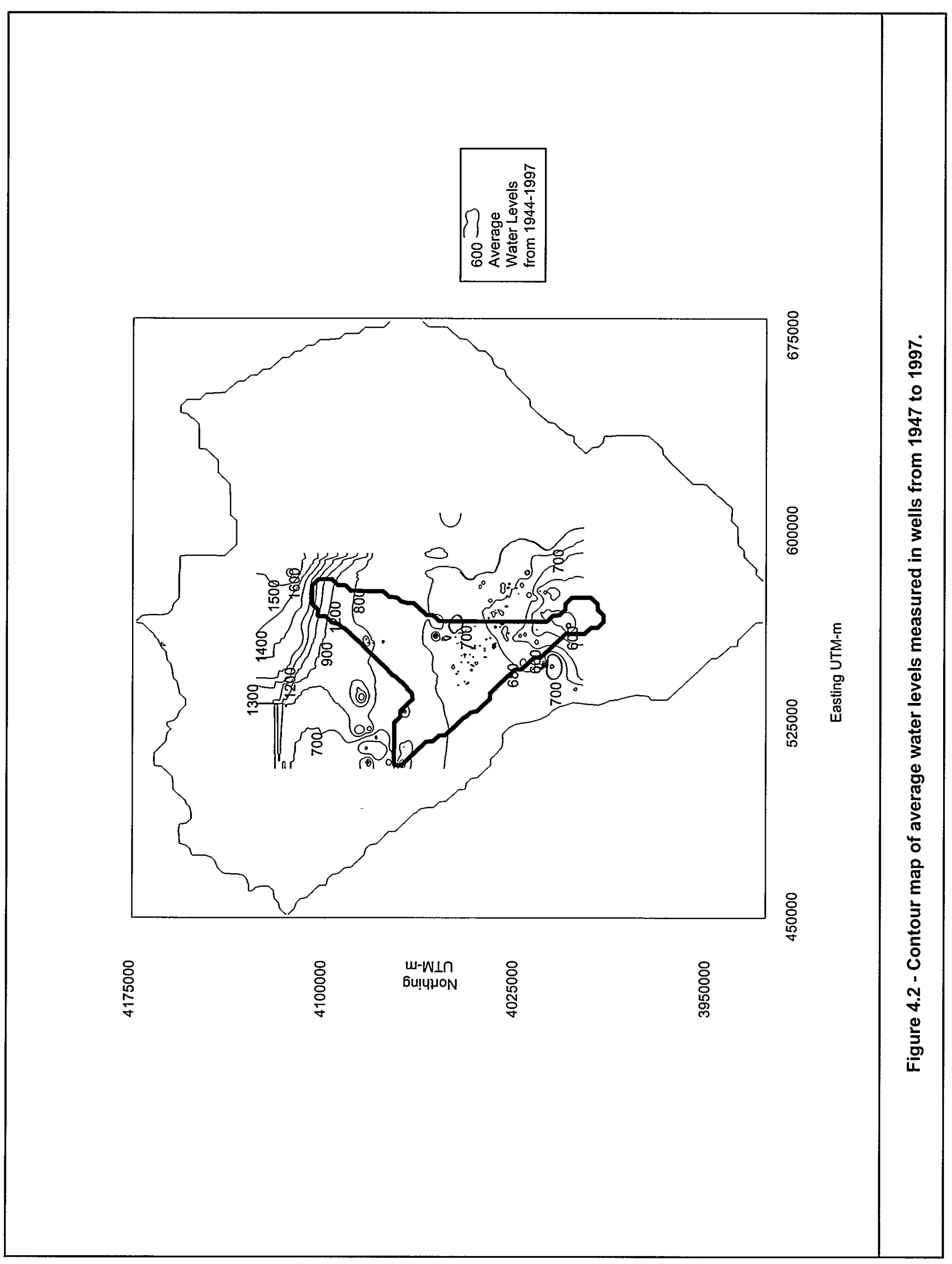




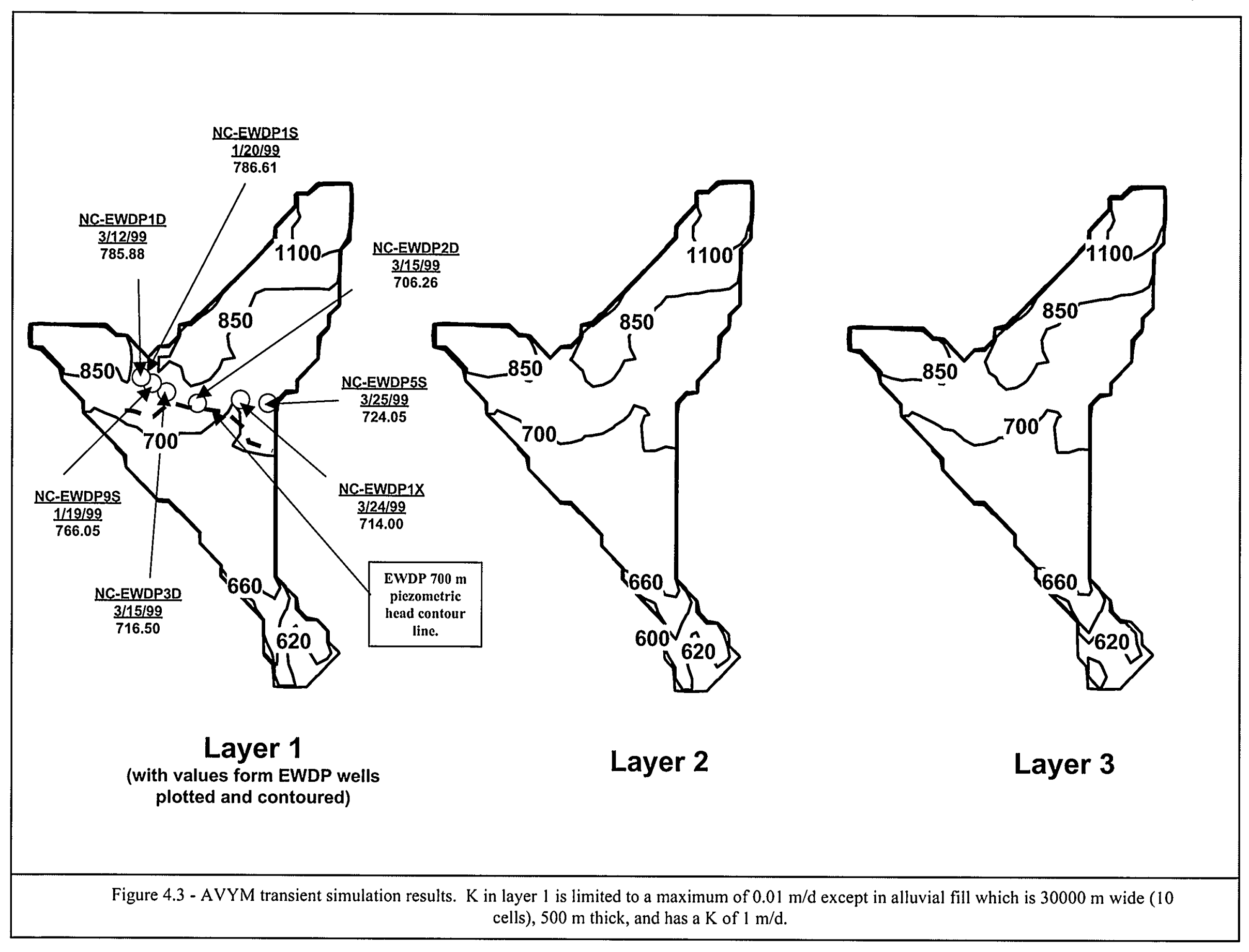




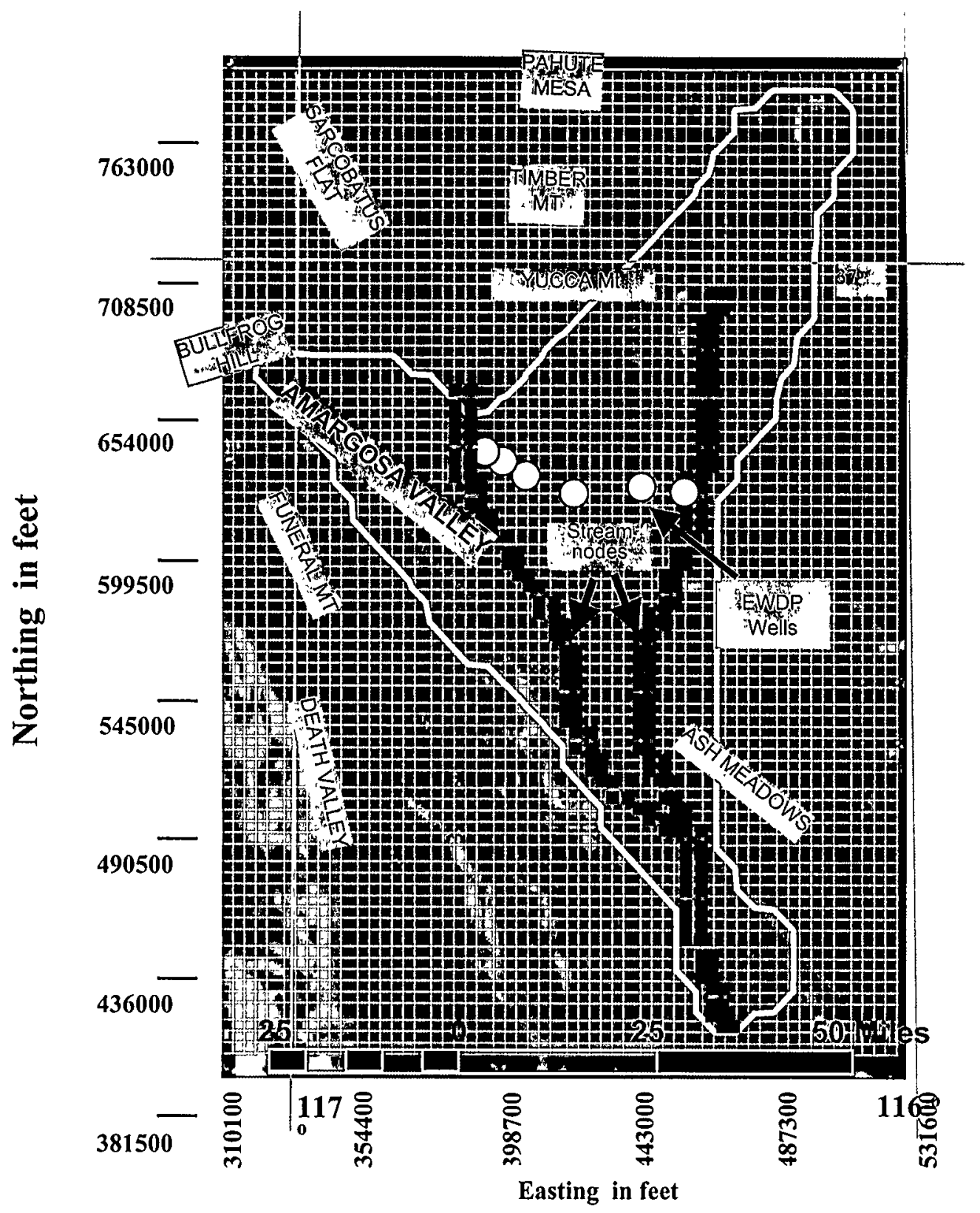

Figure 4.4 - Grid and boundary of the Amargosa valley/Yucca mountain model 


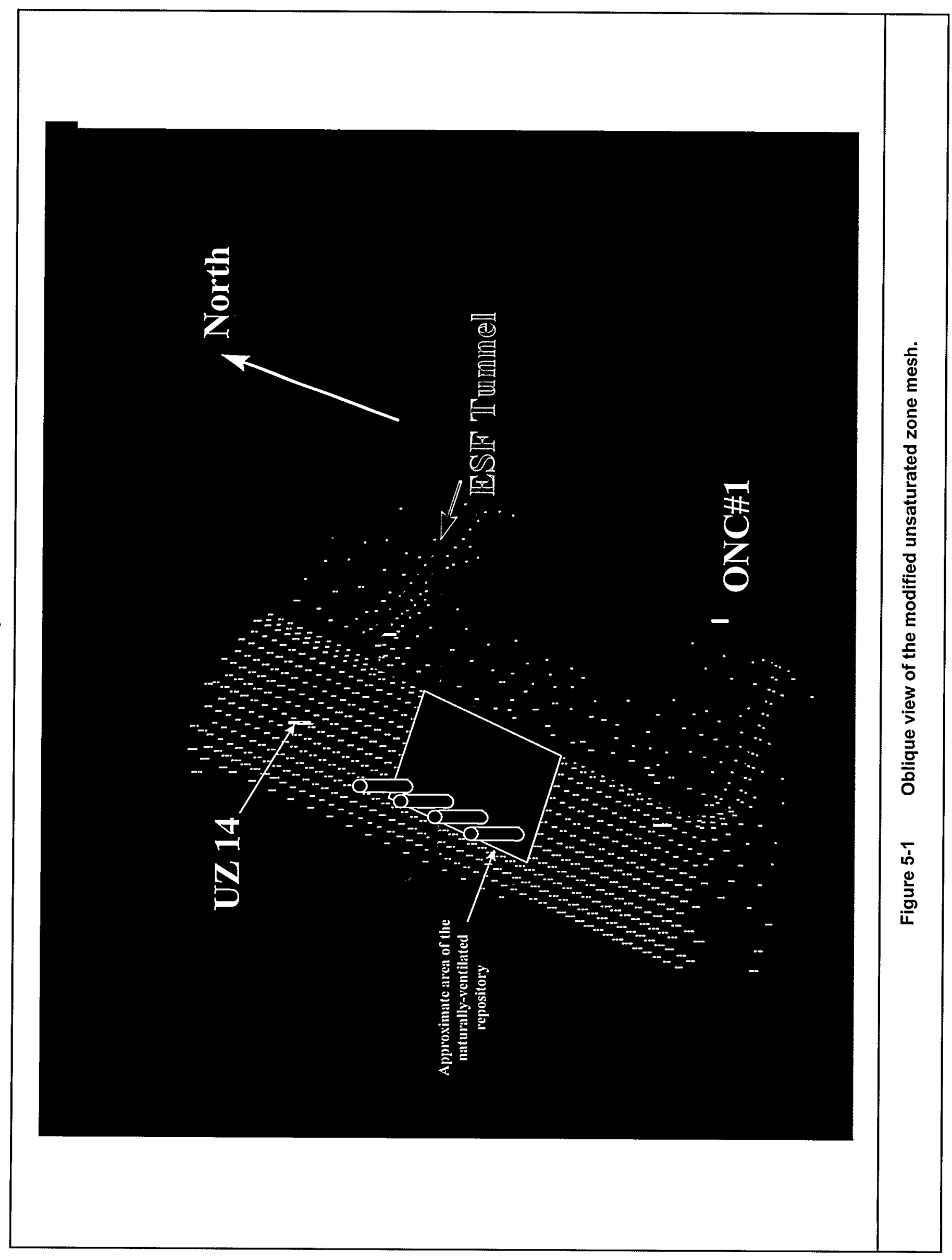

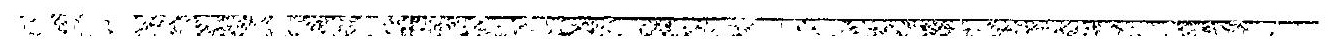

